\title{
Michał Kasiński
}

University of Lodz

Faculty of Law and Administration

Institute of Local Self-Government Law

e-mail: mkasinski@wpia.uni.lodz.pl

\section{Ethical and political dilemmas of local self-government in Poland in the course of systemic transformations (1990-2018)*}

\begin{abstract}
The study presents critical reflections on the course and results of Polish local self-government reforms from March 1990, when after 40 years of the system of territorial soviets (national councils), self-government was reintroduced into communes, until January 2018, when an attempt to improve the systemic institutions of self-government in communes, poviats and voivodships was once again revisited. The author points out significant discrepancies between the basic ethical and political values of local self-government, i.e. democracy, independence and efficiency, and the changing content of self-government systemic laws as well as the practice of local authorities' operations, and formulates proposals aimed at repairing Polish local self-government by adjusting its organisation and functioning to the principles resulting from the Constitution of the Republic of Poland and the European Charter of Local Self-Government. He considers as the most important the elimination of pathological phenomena of simulated local democracy which include: a drastically low turnout in elections and referenda, the disappearance of democratic responsibility of local self-government bodies, and the autonomy of the directly elected executive body of the commune from the influence of the local representation. From this point of view, he positively assesses the new regulations, strengthening the guarantee of transparency of operations carried out by local self-government bodies and control rights of councillors, as well as expanding the catalogue of initiative, consultative and control powers of citizens. He
\end{abstract}

\footnotetext{
* The article is an updated version of the paper published in Polish in the Annales. Ethics in Economic Life, 12(2), 141-153.
} 
points out, however, that ensuring real democracy in of the local authorities requires a deeper reconstruction of the principles of self-government, the election process, and strengthening the role of representation in creating and enforcing the responsibility of executive bodies.

Keywords: local self-government, local democracy, democratic responsibility, local self-government representation, local government unit executive body, European Charter of Local Self-Government

JEL Classification: H70, N44, R50, Z18

\section{The origins of local self-government in Poland}

Historical circumstances of the liquidation of local self-government and the imposition of the Stalinist model of Soviet power in the countries of Central and Eastern Europe at the turn of the 1940s and 1950s caused a much faster erosion of that model than in the USSR itself. One of the important reasons for that phenomenon was the presence in the social consciousness of the systemic alternative in the form of self-government traditions destroyed by the external pressure which were an important component of the sense of national identity and political culture. The vitality of the idea of local self-government in Poland is demonstrated by the fact that despite the great efforts made to remove it from the consciousness of society, the communist authorities themselves decided to refer to it at a time when their social base was rapidly shrinking and the ideology of "real socialism" went bankrupt. In 1976, phraseological changes were introduced into the Constitution of the Polish People's Republic, ascribing to national councils the features of not only organs of state authority but also basic units of social self-government. Under the conditions prevailing at the time, national councils could not fulfil such a role, as they did not come from a democratic choice and were not able to act independently fostering local interests. On the contrary, they were even more strongly associated with the apparatus of the Communist Party and devoid of social influence. It was also a period of deep centralisation of governance of society and management of the economy.

After August 1980, the opposition circles demanded the restoration of real territorial self-government. The programme of "The Self-Government Republic", adopted at the First Congress of the Independent Self-Government Trade Union "Solidarity", was heading in that direction. It included the thesis: "Territorially, organisationally and materially independent self-government must be a real representation of the local community." Marek Śliwiński (2005) has pointed to the social and even the anarchic and socialist character of the programme which postulated workers' self-management at the enterprise level and civic self-governance at the level of a bottom-up built state (pp. 84-85, 140). It did not include the de- 
mand for decentralisation of public authority following the example of the $19^{\text {th }}$-century liberal state, but it also cannot be read as an approval for the then existing centralised system. On the other hand, the project of general reconstruction of the social system towards pluralism and democracy was presented, and the content of that concept showed many similarities to the idea of subsidiarity. After many years, Bronisław Geremek (2002), reminisced in the text intended for an international audience stating that:

The heart of the great Solidarity movement was the dream of freedom and democracy understood as the inherent right of every human being to decide about his own destiny and to share responsibility for the fate of the nation. (p. 122)

The ethical dimension of the original version of the Solidarity's programme is noteworthy. According to Jerzy Regulski, it was supposed to be a programme of the moral rebuilding of society, making it a community based on direct, authentic ties, as opposed to an alienated state and party-government administration (2000, p. 38). Thus understood self-government was an alternative not only to the communist system but also to parliamentary democracy in its traditional form. Local self-government was to be an element of the self-governing Republic of Poland, in which the main role was foreseen for workers' self-government. The implementation of the trade union's programme did not necessarily mean a revolution or a political coupe. Edmund Wnuk-Lipiński (2000, pp. 53-64) sees in the first, romantic period of Solidarity, a culture of dialogue and cooperation, which was later gradually replaced by Lenin's question "who, whom?" The course of social conflicts in the 1980s led to a state in which the culture of dialogue disappeared, and confrontational attitudes, the language of contempt, and hate speech destroyed the credibility of ethical ideals proclaimed by both sides of those conflicts. The Solidarity programme became only a political manifesto of the opposition.

After the imposition of martial law, the struggle for local self-government continued. As a result of subsequent political and economic changes, however, the situation was fundamentally different from the vision that the first Solidarity programme presented. That programme was not implemented at all in terms of internal relations as the transformation of Poland's economic system from the socialist to capitalist one occurred. Śliwiński says that the transformation was almost exclusively the work of the former elites of the Communist Party for whom the inefficient and fossilised real socialism simply stopped being beneficial. The new system was created in the 1980s, despite the resistance and boycott on the part of the then underground Solidarity movement, under the Polish People's Republic's laws and decrees regarding the privatisation of state assets, and its main beneficiaries were high party officials, the members of the government and directors of enterprises involved in the creation of domestic joint stock companies, which were seemingly domestic and foreign-invested enterprises, known as joint venture companies (Śliwiński, 2005). 
Jadwiga Staniszkis describes the process in question as creating political capitalism: the economic class emerging in that period, promoted for that role by political power, sought to obtain a status based essentially on its economic potential (1989, p. 127). That period was characterised by the attempts on the part of the authorities to modernise the current political system in the framework of the socalled plans for the democratisation of public life. In that context, we can observe, among others, a formal (but not political) concession regarding the territorial system, which was expressed in the Act of July 20, 1983 on the System of National Councils and Local Self-Government. It defined national councils as simultaneously the organs of state and local self-government. That concept was contradictory in its nature and could not be reconciled with the classical construction of local self-government (Stahl, 1988, p. 167). In practice, it was also a mystification: council members still could not be elected on a democratic and pluralistic basis and no communal property, which is an indispensable basis for the activity of local self-government, was established. Under those conditions, the law could not fulfil the hopes placed in it.

The incomplete success of reform efforts, the inefficiency of the existing system, and especially the deteriorating economic situation and the total loss of authority of the local administration in the late 1980s prompted the Communist Party to pursue a dialogue with a moderate part of the opposition and search for solutions acceptable to society. At the beginning of 1989, the Round Table Talks became an expression of that dialogue. The compromise also required concessions from the other party. Solidarity parted with the idea of implementing the fundamental theses of the original programme of self-government-based society reconstruction, though not with the thought of local self-government as such.

The compromise concerning the model of territorial self-government was not achieved at the Round Table, though the new concept of the local self-government system presented at the time by the opposition became gradually established in the awareness of politicians and social activists. It was fundamentally contrary to the existing model of national councils, but also different from the one expressed in the first Solidarity programme. The concept did not provide for systemic relations of territorial self-government with other forms of social self-governance, and especially with workers' self-government. In the revised programme, the trade union combined the postulate of rebuilding local self-government with the liberaldemocratic concept of the state, referring to the Worldwide Declaration of Local Self-Government, adopted in 1985 at the World Congress of the International Union of Local Authorities in Rio de Janeiro. In that document, local selfgovernment was defined as an independent unit, separate from the state administration, operating within the framework of state structures whose scope of rights and obligations set forth in the statute (NSZZ "Solidarność", 1989). Such an approach referred to the classical formulas of self-government in the state of law and was previously presented in the liberal circles, the Young Poland Movement and in some intellectual circles. 
The introduction of the new concept into the political circuit is seen as the achievement of the Solidarity-opposition team of experts at the Round Table. Its chairman, Regulski, states that during the negotiations the greatest emphasis was placed on the issues of self-government independence, financial separation, and democratic elections. The government-coalition team, chaired by Sokolewicz, agreed to the majority of those demands. However, the agreement was not officially signed due to the existence of differences in views on three issues. The government side demanded the retention and the Solidarity side demanded the removal of the constitutional definition of national councils as organs of state authority and self-government. The government wanted to introduce full voivodship selfgovernment, with legal personality and its own property, along with general elections to voivodship councils (being concurrently state bodies). The Solidarity side believed that in the first stage of the reform, commune-level self-government ought to be established, while voivodships should be left as territorial units for the purpose of government administration, including, however, the representation of communes from the voivodship area endowed with social control competencies. The government side demanded that the state administration is maintained in communes alongside self-government, and the local self-government side demanded the liquidation of that administration (Regulski, 2000, p. 50 et seqq.). Those discrepancies between the positions of the negotiators and the limited possibility of reaching a compromise were in a sense understandable. The negotiators were not political decision-makers, but they realised that it was a discussion on the fundamental and lasting transformation of the system.

From today's perspective, it can be seen that the debate taking place then was a sign of a revival of a culture of dialogue and cooperation. Only on the basis of such a culture, relying on models of understanding among people with diverse points of view on public affairs, different world outlooks, social views, and even competing political interests, authentic and lasting democracy can be built.

\section{The first stage of the local self-government reform (1990-1997)}

The local self-government reform became possible after the victory of Solidarity in the parliamentary elections on June 4, 1989. On the initiative of the Senate, after a long-standing discussion and legislative work, on March 8, 1990, the Sejm (the lower chamber of the Polish Parliament) passed the Act on Local SelfGovernment (consolidated text in Journal of Laws, 2001, No. 142 as amended, currently entitled: Act on Commune Self-Government, consolidated text, Journal of Laws, 2018 item 994). On the same day, the Sejm adopted a constitutional amendment introducing the provisions that the Republic of Poland guaranteed the participation of local self-government in the exercise of power. The Sejm also passed commune council electoral regulations, and after a dozen or so days, the Act on Local Self-Government Employees, regulating, among others, issues of granting property rights to communes and the creation of civil servant corps 
of self-government administration. The dualistic model of the territorial system was complemented by the Act on Territorial Organs of General Government Administration and the so-called Competence Act. Elections to commune councils took place on 27 May 1990, and thus the first stage of the local self-government reform in Poland began.

The victory of civic committees in the first local elections was assessed, rather prematurely, as the actual collapse of the bureaucratic-centralised system, as empowered local communities transferred along with the electoral mandate the power to local power structures (Buczkowski, 1997, p. 219). Others considered the voter turnout as a measure of success, and that was disturbingly low (42.7\% of those eligible to vote). Despite this fact, success was actually achieved and consisted not so much in filling $50 \%$ of seats by candidates of citizens' committees but in the social qualifications of new councillors and obtaining a high degree of representativeness of commune councils. The basis for that success was the electoral law which created a wide range of opportunities for local communities, groups of citizens and their various organisations to propose candidates for councillors, without granting any preferences to political parties. Andrzej Piekara points out that all that resulted in favourable circumstances for genuine and creative stimulation of socio-political life, especially the social activity of microcommunities. Also, conditions for positive selection of candidates for local authorities, based on substantive and civic criteria of evaluation, appeared. The beginnings of authentic, pluralistic public opinion related to the election campaign emerged. Most importantly, the voters became convinced that they could make decisions on the composition of the most important authority: the commune council. The local authority met the conditions for its democratic legitimisation and social acceptance (2005, pp. 147-148).

The systemic model of local self-government introduced in 1990 corresponded to the classical western (continental) models and to a large extent referred to solutions from the interwar period. However, it differed from those models in that it was a one-stage model. Only communes, both in urban and rural areas, were recognised as local self-government units by virtue of law. They could merge into commune unions and also had a voivodship representation (the regional assembly), but there was no self-government at the higher level. The voivodship was defined by law as a territorial unit created for the implementation of government administration by the voivode and its apparatus. For the same purpose, the voivodship was divided into districts of general administration in which only governmental bodies operated - the heads of district offices. The voivodes were granted strong supervisory powers towards commune self-government, whereas commune self-government was given substantively limited competences as well as inefficient and unstable financial sources of its operations.

The recognition of the commune as the basic local community of residents, competent in public matters of local importance not reserved for other entities, and the creation of a legal way for communes to form a supra-commune level for performing public tasks in the form of a voluntary commune union was an important step towards the principle of subsidiarity. An important democratic feature of the 
new territorial system was granting residents of the commune the right to decide directly on all important matters of the commune through a local referendum (regarding the commune council recall and self-taxation for public purposes on an exclusive basis), the free election of councillors according to the rules ensuring the representative character of the governing body, the election of the executive body (the commune board) by the commune council and its responsibility before the council. Decentralisation to the level of the commune expressed itself in the creation of a guarantee of carrying out independent actions in the scope of its own tasks and the right to take legal action against unlawful interference of the supervisory authority, the introduction of commune property, the determination of sources of its own revenue and subsidies from the state budget based on objectified criteria, as well as the creation of a new professional category of local selfgovernment employees. A strong advantage of the 1990 reform was the introduction of self-government to existing communes, without the need to correct the territorial division. The network of communes was shaped already in the 1970s relatively rationally, as most communes had social and economic ties formed to implement public tasks. Communes as territorial units were in principle prepared for the adoption of the local self-government system. This is one of the main reasons for the success of the commune reform (cf. different assessments of the reform in Piekara (2005, p. 151) and Regulski (2000, p. 367 et seqq.)).

The provisions of the Constitutional Act of October 17, 1992, the so-called Small Constitution, recognising local self-government as the basic form of organising local public life, the commune as the basic unit of this self-government, and the possibility of creating other units through the statue, were undoubtedly the manifestation of decentralisation and self-governmental trends (published in the Journal of Laws, No. 84, item 426). Also, the adoption of the Act of 7 October 1992 on the Regional Chambers of Accounts (consolidated text in the Journal of Laws, 2016, item 561 as amended) as well as the Act of October 12, 1994 on Local SelfGovernment Appeal Boards (consolidated text in the Journal of Laws, 2001, No. 79, item 856 as amended), and especially the ratification of the European Charter of Local Self-Government in 1993 (in the Journal of Laws, 1994, No. 124, item 607 with corrections) pointed to the intention to consolidate the independent position of local government units in the public authority system. However, it did not mean that decentralisation was recognised as a fundamental, lasting and integral principle of that system. Despite the removal of the hegemony of the Communist Party, the failure of the local self-government reform still loomed ahead.

It was an imperfect, unfinished reform. The political solutions of the first half of the 1990s did not lead to the dismantling of the centralised and bureaucratic system of state governance; they only made a breach in the system, increasing in fact its disfunctionality. Its higher levels were left almost entirely under the control of hierarchically organised government administration bodies. There was no reform of the territorial division necessary to allow for the regionalisation of the country. Local authorities were not provided with stable and sufficiently efficient sources of income and independence in making budget expenditures and managing communal property. After the SLD-PSL (SLD-Democratic Left Alliance; 
PSL_Polish People's Party) coalition took power (1994-1997), decentralisation was stopped halfway, threatening to return to the full version of the centralisedbureaucratic model in governance of society and management of the economy.

\section{The second stage of the local self-government reform (since 1998)}

It was necessary to wait for fundamental changes almost until the end of the $20^{\text {th }}$ century. In 1997, the new Constitution of the Republic of Poland was enacted and adopted by the National Assembly in a referendum. In June and July 1998, on the initiative of the centre-right government of Jerzy Buzek, the Parliament enacted the systemic laws marking the second stage of the local self-government reform. ${ }^{1}$ The 1998-1999 reform assumed the creation of a new territorial system of Poland and the building of civil society institutions in accordance with the principles of decentralisation of public authority and subsidiarity set out in the new Constitution. The decentralisation of public tasks was aimed at limiting the central administration's activities to managing changes of strategic importance and pursuing the policy of protecting the national interest in the administration process. The remaining tasks were to be carried out by the territorial administration at the regional and local level. At the regional level, both decentralised local self-government and territorially decentralised government administration were established. The basic task of voivodship self-government was guaranteeing the civilisational development of the region, mainly through the determination and implementation of its regional policy, and the organisation of public services within the voivodship. The government administration under the authority of the voivode as a representative of the Council of Ministers was assigned the role of protecting the uniformity of the state and national interests. For this reason, the voivode was granted the competence to coordinate the activities of all governmental (combined and noncombined) units in the voivodship, adjust the government policy implementation to the voivodship conditions, supervise public law entities, including local selfgovernment, as well as ensure public safety and order in the voivodship.

At the local level, all public tasks were entrusted in principle to selfgovernment organised on two levels: the already existing commune level and the new poviat one. Their role was defined as the implementation of their own tasks in order to meet collective needs of residents of a given commune or poviat as well

\footnotetext{
${ }^{1}$ Act on Poviat Self-Government of 5 June 1998 (consolidated text in the Journal of Laws, 2018, item 995), Act on Voivodship Self-Government of 5 June 1998 (consolidated text in the Journal of Laws, 2018, item 913), Act on Government Administration in the Voivodship of 5 June 1998 (in the Journal of Laws, No. 91, item 577), replaced by Act on the Voivode and Government Administration in the Voivodship of 23 January 2009, (consolidated text in the Journal of Laws, 2017 item 2234), Act on the Introduction of the Three-tier Division of the Country of 24 July 1998 (in the Journal of Laws, No. 98, item 603, as amended).
} 
as government administration tasks stipulated by statutes and entrusted to it on the basis of agreements. Poviat self-government was to carry out supra-commune tasks, with the exception of conducting business activity.

The introduction of the three-tier basic territorial division was considered a necessary condition for the implementation of the reforms. The most important from this point of view was the creation of voivodships, which due to their area, population, social situation and economic potential could be considered as selfgovernmental regions, corresponding to European standards. A three-fold reduction in their number (16 instead of 49) was supposed to remove an obstacle to the regionalisation of Poland expected by the main bodies of the European Union. A by-product of the creation of large voivodships as self-governmental regions (more precisely self-governmental and governmental ones) was the restoration of poviats. Far too many poviats were created from the point of view of the requirements of rational governance, as many as 308 the so-called rural poviats (after two years, 7 more, and so 315 in total). However, there were no changes in the number of communes or their statutory model, except for the creation of 65 towns with the rights of poviats. An important reform of commune self-government was carried out in 2002, replacing the previous collegial boards elected and recalled by commune councils with the new single-person executive bodies of communes: commune heads, mayors and city presidents, elected directly by residents and recalled before the end of the term only through a local referendum. ${ }^{2}$ Unfortunately, the last reform served not so much the development of local democracy as the transformation of the influence of political parties on the functioning of the commune authority centre. It fundamentally changed the system of power in communes, destroying the pervious relative balance of power between legislative and executive bodies in favour of the clear dominance of the latter.

\section{The consequences of the reform: the success or crisis of local self-government}

According to the intentions declared by the creators of the reform, it was aimed at improving the system of public authority in Poland, ensuring higher efficiency than before in solving social problems and the functioning of local units in accordance with the principles of democracy, social pluralism, decentralisation and subsidiarity established in Europe. From the perspective of past years, it can be stated that the manner of introducing systemic changes and their consequences did

\footnotetext{
${ }^{2}$ Act on Direct Elections of the Commune Head, Mayor and City President of 20 June 2002 (in the Journal of Laws, No. 113, item 984 as amended) expired. Currently: Act on the Electoral Code of Poland of 5 January 2011 (consolidated text in the Journal of Laws, 2018 item 754), Act on Local Referendum of 15 September 2000 (consolidated text in the Journal of Laws, 2016, item 400 as amended).
} 
not fully correspond to the presented assumptions. In addition, after the entry into force of the laws introducing the reform, social and political phenomena which hindered or prevented the implementation of some of its objectives occurred.

The 1998-1999 reform did not include the reconstruction of the state governance centre; hence the structures of ministries and central offices were not adapted to the situation in which they no longer implemented separate ministerial policies. As a result, the reform consisted to a significant extent in the "decentralisation of budgetary difficulties." In the first years, numerous dysfunctions appeared related to the transfer of new tasks to the self-government of voivodships and poviats without providing funds for their implementation, for example, in the field of health protection, education, social policy, environmental protection, unemployment and employment promotion, modernisation of rural areas, or the management of public roads. In those areas, there continued to remain governmental specialised administration departments whose maintenance still absorbed a significant part of budgetary funds or separate funds.

Those defects were corrected in the following years, mainly by creating a stronger basis for the regional development policy implemented by voivodship self-government. In particular, the financial equilibrium of many local government units at this level could already be obtained to a greater extent by means of financial resources from the European Union Structural Funds. Until recently, there was a tendency to expand the scope of activity of voivodship self-government, primarily at the expense of voivodes, concurrently the duties of co-operation in the scope of implementation of developmental tasks were imposed on the voivode and local self-governments. Nevertheless, the internal integration of self-government within the boundaries of individual voivodships remains weak; the underdevelopment of ties between local self-governments and voivodship self-government in the scope of shaping the content of basic legal documents concerning regional development is still noticeable. In fact, communes and poviats have an insignificant influence on the content of the voivodship development strategy, the regional operational programme and voivodship programmes adopted by the regional assembly. They are mainly petitioners of voivodship authorities in the procedures for obtaining aid funds. The political mechanism of decision-making processes in voivodship selfgovernment enables the management of its activities by the central national parties that have factions (councillors' clubs) in the regional assembly and representatives on the voivodship executive board, leaving no room for a greater influence on these processes to be exerted by local self-governments and non-governmental organisations. In the relations between communes and poviats and voivodship self-government, it is difficult to find important elements of the implementation of the constitutional principle of subsidiarity.

In the last two decades, at both levels of local self-government, there have been more or less successful systemic changes aimed at strengthening the democracy and the efficiency of the functioning of the commune or poviat authority. The scope of civic participation has been increased and new institutions have been launched (e.g.: opinion-providing referenda, civic legislative initiatives, civic budgets in some cities), and the rules for cooperation between self-government 
authorities and non-governmental organisations have been regulated. Since 2002, the aforementioned changed legal model of the executive body has prevailed in communes, and in poviats the traditional model has been maintained: the collegial board is still elected by the poviat council, but the position of its chairman (staroste) has been strengthened along with his or her single-person competences, especially in the field of control over poviat services, inspection bodies and guards (police, state fire brigade, construction inspectorate, and sanitary inspection). A not very effective attempt has been made to realign the accountability of the decision-making bodies (commune councils, poviat councils), and in communes also the executive bodies, to residents, mitigating the validity conditions of the recall referendum (submission of valid votes by at least $3 / 5$ participants of the last elections for the recall-threatened body). The legal possibilities of playing a creative role in the field of local development by local and regional self-governments have been extended, but these possibilities are being used to a small degree. All this has proven to be insufficient to stop the return of centralistic and bureaucratic tendencies in the functioning of local self-government as well as the entire public administration. One of the reasons for this process is excessive politicisation (in the sense of being party-bound) of the activities of self-government bodies, especially in larger cities and poviats. For many years, it was considered a consequence of a faulty electoral law favouring voting based on party lists and the distribution of seats according to the principle of proportionality. Less attention was paid to the style of activity of party council clubs. Meanwhile, the credibility of the constitutional and statutory construction of the free mandate of selfgovernment councillors is questionable, since they are chosen by residents but mainly among candidates of one or other party, and when making important decisions they are bound by the party (club) discipline. These two factors essentially limit the scope of representation by councils of interests other than political ones present in the local community as well as the influence of non-party organisations and social communities on the way of solving problems related to meeting residents' needs. The introduction in 2014 of the principle of majority elections to commune councils in single-mandate constituencies (apart from towns with poviat rights), contrary to expectations, has not improved the situation, as on the scale of the country candidates of national parties have won more votes than others. The causes of this phenomenon may vary. The most important, in my opinion, is the inconsistency of the reform. It has not encompassed the other of the abovementioned factors: the legal status of the councillor has not changed; it is not strictly related to the protection of voters' interests, and especially to keeping electoral promises. Residents may still recall the whole council in a referendum, but they cannot recall a single councillor who has compromised his or her vow or has otherwise lost social credibility. One of the main reasons for the alienation of elected local authorities has not been removed, which has had a negative impact on their social authority and the ability to effectively solve the problems of collective life. 
This alienation has not been removed by the functioning for four terms of the model of single-person executive bodies of communes elected directly by residents. However, it has caused a disruption of the mechanisms of self-government representation and threatened the continuity of power in the commune. Commune heads, mayors and city presidents have become largely independent of commune councils (city councils), leading to a significant reduction in the role of the latter: by losing the right of recall of the executive body, councillors have been deprived of the basic instrument to enforce the execution of their own resolutions.

Contrary to the widespread myth, the vast majority of heads of commune executive bodies have not obtained the position of political leaders in the system of local authority. This is particularly true of the presidents of large cities. Although they have been freed from the imperative pressure of political groups dominating in the councils, the leadership of the regional party branches still has formal and informal channels of direct influence on their people holding offices in the cities, even if they do not act under the party's name. Moreover, more strongly than before, they are dependent on their own bureaucratic apparatus, and they can also become hostages of economic interest groups which through their own dominating influence on the local government apparatus gain an advantage over competitors and other centres of social influence.

Residents' lack of faith in the effectiveness of enforcing the democratic responsibility of self-government authorities, especially commune heads, mayors and city presidents, means that there are few recall referendums, and most do not bring legal solutions due to a low number of participants. There are quite common cases when a commune head, mayor or city president who has not received a discharge for the budget or for some other reason has lost the trust of the commune council (city council), e.g.: evidently acting to the detriment of residents, still performs the function after "winning" the referendum in which fewer than $3 / 5$ of the participants of the elections in which the person had obtained a mandate took part. Democratic legitimisation of such commune authorities may raise serious reservations.

In rural poviats, on the basis of a different legal regulation of the mechanism of responsibility of the democratic executive body (recalled by the council, not the residents), symptoms of the crisis of this institution are also present. The staroste often obtains a dominant position not only in the collegiate executive board but also in relation to the poviat council and becomes virtually irremovable until the end of the term. This is the consequence of the unsuccessful concept of the poviat as the second level of local self-government, fulfilling the tasks related to supracommune duties but not conducting business activity. From the very beginning, the poviat became an administrative-bureaucratic entity; its authorities are bound not so much by the will of residents as by various interest groups influencing political groups holding the majority in the council and in the poviat executive board. Another serious disadvantage of the system of the poviat is a lack of a systemic connection of the activities of its authorities with the interests of communes belonging to a given poviat, and thus the failure to respect their fundamental role in the system of public authority and the constitutional principle of 
subsidiarity. Also, the concept of towns with poviat rights, being an attempt to distinguish the legal category of large cities without violating the dogma of the need to preserve the uniform status of the political system of the commune, has proven to be unsuccessful.

Local (as well as regional) self-government partiocracy is one of the manifestations of appropriation of the Republic by the central apparatus of nationwide political parties. Against this background, the consequences of perceiving in the mechanisms of the operation of the self-governmental representation primarily the arena for political games and the bureaucratisation of the functioning of executive bodies along with their isolation from the influence of the legislative bodies and local society are becoming increasingly visible. There is also a noticeable tendency of central offices and leaders of political groups to directly control decision-making processes in local self-government through issuing instructions and orders to party councillors' clubs as well as party activists holding managerial functions and occupying prominent positions in the executive bodies. Especially at the level of the voivodship, this leads to the removal of the features of authenticity from self-government and to the reduction of the role of regional self-government communities to pure fiction. These negative trends are also present in local selfgovernment. On the other hand, the results of empirical research indicate the tendencies of the local elites to closing themselves off, isolating themselves from the rest of the residents that are often seen as a group of passive public service consumers, able only to choose between providers of these services. Public life abnormalities in the form of mafias or local cliques occupying centres of selfgovernment power for subsequent terms can be observed (cf. Kurczewski, 2007, p. 571 et seqq.).

As a result, two concepts of "therapy" of Polish self-government, which may prove more harmful than its diseases, appear more and more clearly. The first is based on the belief in the omnipotence of market mechanisms in social life, spread with obstinacy, without any basis, along with a new dogma about the necessity of full privatisation of public services. The experience of countries where such reforms have been carried out, leads to far-reaching caution in their recommendation. In particular, the trend towards the focus on only economic indicators of the effectiveness of local authorities' operations, the understanding of their mission as similar to the role of management boards of commercial companies is dangerous. Short-term effects of such an approach may be attractive; the extraordinary success in acquiring and using European funds in Poland is attributed to the business efficiency of commune heads, mayors and city presidents. In the long-term, such reforms, however, result in the loss of access to services by less affluent members of the community, the deterioration of their living conditions, and thus the loss of trust in the elites, and the breakdown of ties that unite the local self-government community (Dębicki, 2001).

The other concept is expressed in the intention of "nationalising" of selfgovernment, and at least subjecting local and regional authorities to intense supervision by the government administration, including also political pressure. One cannot underestimate the temptation to de facto assign self-government authorities 
a role similar to that played by national and local state administration bodies. The tendency to introduce changes in this direction has clearly appeared over the last two years. Under various pretexts, the scope of tasks of local self-government units and the competences of self-government bodies are being limited and not only individual institutions but entire areas of competencies of self-governing bodies (e.g.: water management in the voivodship) are transferred to the competences of voivodes and other bodies of combined administration and existing or newly created bodies of non-combined government administration. The repressive character of supervisory control of self-government exercised by the governmentappointed voivodes is increasing, which is indicated by, among others, cases of expanding their interpretation of the premises for a "substitute" termination of mandates of commune heads or mayors due to the alleged violation of the socalled anti-corruption provisions, when the commune council refuses to apply this measure, or issuing discretionary supervisory decisions in matters of the so-called de-communising of the names of streets and squares.

The values of liberty and democracy of local self-government are protected by the constitutional principles of decentralisation and the participation of selfgovernment in the exercise of public authority, at least as long as independent judges stand guard over these provisions. However, they do not eliminate the described threats completely. These rules may be subject to reinterpretation leaning towards the monism of the local authority. The essence of a monistic system is not in conflict at all with formal and legal declarations on decentralisation and local democracy. In practice, the relationship between these concepts can be severed, and they can be deprived of their true social meaning. It is enough that those in power in the commune, poviat and voivodship will feel empowered to unilaterally determine the content of public interest and behaviour of residents' dependent on their will, not allowing residents to co-decide, and depriving them of the space necessary for pursuing individual and group interests that are in need of protection. The liberal facade of the local government system can still be maintained, but the actual political and social pluralism is missing (more in Kasiński, 2009).

Political orientation and party affiliation of "local leaders" or "managers" understanding their role in such a way is not really important here, as they become a part of the monistic system that hijacks the entire public sphere, the system whose distinguishing feature is the hegemony of the bureaucratic apparatus of power, separated by a "glass wall" from society, and a sharp caesura between the rulers and the ruled. A negative feedback occurs: the weakening of the elements of democratic ideas and pluralism on the national scale contributes to similar processes in territorial units and vice versa: the tendency of introducing changes in the system of central government leading towards bureaucratic (and even police) monism is supported by analogical changes in the territorial system.

Some changes introduced at the beginning of this year in the systemic model of local self-government seem to be heading in a different, pro-local and democratic direction, e.g.: giving the statutory status to citizens' legislative initiative rights and the institution of the civic budget, granting councillors the right of submitting questions, imposing on councils the duty to define the rules for consulta- 
tions and establishing committees dealing with citizens' complaints, motions as well as petitions and on the executive authorities the duty to submit reports on the status of a given unit at the council session each year as well as to subject the report to the public debate with the participation of residents, introducing the right of refusal of the vote of confidence as grounds for initiating by the commune council a referendum on the recall of the commune head and as the premises for the recall of the executive body by the poviat council or the voivodship assembly (apart from the refusal to grant the vote of approval and "another reason"). ${ }^{3}$ The practical importance of these solutions, however, can only be evaluated after the next term of office. It will take a long time to assess the consequences of limiting the permissibility of holding the office by a commune head, mayor or president to two terms, due to their extension to five years.

Such innovative measures cannot, however, overshadow the importance of the most significant change, which will have consequences in the results of the last elections: the retention of the majority rule for commune councils in singlemandate constituencies only in communes of up to 20,000 inhabitants, in other communes the restoration, and in cities with the poviat status, rural poviats and voivodships the maintenance, of the principle of proportional elections in multimandate constituencies, which will provide stronger preferences for candidates from party lists. It will also serve to unify the principles of shaping the composition of representative bodies "from top to bottom", at all levels of the political system-from the Sejm to commune councils (except the smallest communes), thus restoring or strengthening the partiocracy - probably considered to be beneficial from the point of view of effectiveness of exercising the political control over the state and social organism at all levels. Since the legal structure of the councillor's mandate has not changed: it is free from voters' instructions but depends on party instructions imposed, for example, as part of disciplining members of councillors' clubs. Legal regulations established in order to increase the influence of residents on public authorities may in these circumstances serve to strengthen the influence of local or regional party leadership on the activities of local selfgovernment representations and their executive bodies. The leadership body of the ruling party (coalition) does not really conceal the intention to continue the process of centralisation of public authority and state interference in local selfgovernment. Perhaps the leadership is unaware that it is following the well-worn path leading to various, seemingly already overcome, varieties of centralism that only appear to be democratic. Thus, one should bear in mind Kumaniecki's warning: centralism always has a cataclysm at the end of its path (1924, p. 133).

\footnotetext{
${ }^{3}$ Act of 11 January 2018 Amending Certain Laws to Increase Citizens' Participation in the Process of Election, Operation and Control of Some Public Bodies (in the Journal of Laws, 2018, item 130).
} 


\section{Conclusions}

The experience of the Polish transformation indicates that the introduction of the legal principle of political pluralism does not guarantee a deep reconstruction of the social system aimed at the authentic empowerment of individuals and social groups. After almost thirty years since the beginning of the systemic transformation, the degree of real self-organisation of society and public involvement in public life should be assessed as still remaining highly unsatisfactory. One of the signs of this situation is the growing crisis of local self-government, manifested not only in a low turnout in local self-government elections (since 1990 it has never reached $50 \%$ of eligible persons throughout the country), but in general in the weakening relationship between its institutions and direct representative local democracy, especially in the drastic disappearance of democratic responsibility of local self-government authorities. For the first time in recent Polish history, the trends of local democracy development collided with a strong technocraticbureaucratic counter-trend, this time tinged with vulgar economism or a poorly concealed longing for authoritarian solutions.

The idea of establishing the so-called single-person local leadership, i.e. the executive bodies pushing the institutions of the local self-government representation into the shadow at all levels of these authorities, is particularly controversial. I believe that authentic Polish leaders with appropriate experience and talent, and the trust and support of the people should manage the communes and other local government units. It is necessary to create premises, including legal ones that could ensure the selection in the democratic mechanism of people with such characteristics and skills as well as the willingness to act for the benefit of residents in cooperation with active citizens - members of the local community. In practice, however, these are two different types of political personalities. Some politicians consider their activity to be public service, while others undertake such activity to gain prestige, power, and related profits. Such politicians are called ruthless political players, as their actions are subordinated to self-interest instead of public goals (Jakubowska, 2002, p. 83). I express my fear that under current political and legal conditions when a party-based or clique-occupied centre of local authority is increasingly isolated from the social forces in the local self-government community, it is easier to promote ruthless political players, local or regional caciques and mandarins. Unfortunately, some terrible force has been pushing local selfgovernment in Poland in this direction for a long time.

To stop these negative processes, it is necessary to awaken the social will to restore the fully democratic character of local self-government so that it can be credibly called a civilisational value and an authentic institution of civil society. Pluralism of the public system cannot bring the expected results if it is not associated with legal and extra-legal factors that stimulate citizens to participate in public life at all levels of the political organisation of society. Ensuring effective, twoway communication between socially active individuals as well as social groups and the centre of local authority is such a factor. In the battle for the necessary 
reform of public authority, the first demand should be made to base its system on the principle of subsidiarity, meaning "strengthening the role of citizens and their associations." Clear recognition is needed in the new or amended Constitution of the Republic of Poland of commune residents' communities as primary entities of self-governing units, and their authority should be based on "double legitimisation": derived from the statutory act and at the same time rooted in the natural rights of the commune resident-to self-govern. The state, in recognising the Constitution as the subjective right of an individual to realise together with other individuals (neighbours) the common good in the framework of a selfgovernmental community, would have the characteristics of a democratic state of law respecting the principle of justice in the deepest sense of the word.

The literature emphasises that modern democracy combines the conviction about the natural right of all citizens to participate in making basic political choices with the equally natural right of everyone to enjoy freedom in every sphere of life, and this freedom can be limited only if it is necessary to protect the freedom of individuals and groups (Izdebski, 1993, pp. 51-52). In my opinion, this idea should inspire a way of understanding not only individual but also collective civil rights. Since the system of the modern democratic state combines majority-rule with respect for individual and minority rights, the law of this state cannot ignore the natural right of individuals to the mutual provision of assistance and the association for the implementation of the common good. On the contrary, statutory law should be aligned with, support and protect these natural laws. This is an indispensable condition that determines the building of a healthy society and state that serves its interests. Only in this way can one overcome the antagonism between society and the state in a manner consistent with the axiology of democracy. The implementation of this requirement in the Constitution and legislation can be carried out by following two paths: guaranteeing the freedom of association in voluntary social organisations and creating the institutional framework and basis for the operation of self-government communities, which by virtue of acts of state law participate in the exercise of public authority.

I share the view that local self-government is a method of the political organisation of the state: in the sociological and political sense, it combines the features of a natural community of residents with certain features of the legislative and executive authority (Dębowska-Romanowska, 1994, pp. 7-8). In the light of Article 3 Paragraph 1 of the European Charter of Local Self-Government, this means "the right and the ability of local authorities, within the limits of the law, to regulate and manage a substantial share of public affairs under their own responsibility and in the interests of the local population." The Republic of Poland, by ratifying the Charter, committed itself to respect such an understanding of selfgovernment: it is the right of the local community to make decisions about its affairs and the ability of this community to independently govern and manage its affairs. Local communities do not evolve from the will of the state that only delineates their boundaries, determines the basic features of the public system and defines the framework of their independence. It is true that the state forms the basis for the decision-making actions of a community transforming the 
corporation of citizens into self-government. However, a democratic state must recognise citizens' rights to local self-government; it cannot deprive local authorities of responsibility for the way and results of managing local affairs. Democratic local government authorities should respect the legal provisions, but they should also be aware that they govern to represent residents' interests and with residents' involvement.

The demolition of the left-over from the previous system and now newly built wall separating the centre of local authority and residents that are subordinate to this authority requires, in my opinion, two types of reformatory actions. First of all, it is necessary to make the forms of direct democracy truly real: referenda and local elections as well as social consultations. Practices in the light of which these forms become a parody of democracy (simulated consultations), a testimony to unused democratic opportunities (a low turnout in referenda and elections) or an arena of scandalous political and personal games that are in opposition to the standards of democratic culture should not be tolerated. Secondly, more effective instruments of exerting the influence of citizens and their various associations on the functioning of local self-government bodies are needed. Legal regulations in the light of which the so-called delegation democracy, i.e. reducing residents' activity to the choice of the council members and possibly the executive body, is permitted have proven to be dangerous, as they may result in the formation of local and regional "power groups" that are not controlled by society.

Tools of legal protection against these pathological phenomena can be seen in the new provisions of Act of Local Self-Government of January 2018, providing for the reconstruction of procedures allowing residents' access to decision-making processes in the council or the assembly, guaranteeing their transparency, and extending the catalogue of initiative, consultative and control powers in this area. However, the introduction of an effective mechanism of democratic choice and democratic accountability of councillors and the executive body would be a decisive step. Commune councillors elected by residents in single-seat constituencies and communes should be given the right to choose the commune head, mayor or city president if no candidate has obtained at least $50 \%$ plus one validly cast votes in the general election. It would make the second round of elections - a procedure that has little to do with real democracy-unnecessary. The commune council should also be granted the right to recall the commune head that has lost its trust if less than $50 \%$ plus one of eligible population participated and cast valid votes in the recall referendum held at the initiative of the council. Only then will it be possible to speak of the full compatibility of the national commune system with the European Charter of Local Self-Government, which in Article 3 Paragraph 2, obliges the council (or assembly) to provide the council (or assembly) with sufficient competence to recall the subordinate executive body.

Is fulfilling the demand for reform in order to protect the most basic values of self-government: democracy, independence, and efficiency of local authorities realistic? One cannot be under the illusion that the change of the ruling party to another one would reverse or hinder dangerous trends of legal transformations of the laws on local self-government in the direction of destroying these values. 
Their survival requires an agreement over political divisions, unfortunately only possible on the grounds of the now-defunct culture of dialogue and cooperation.

\section{References}

Act of 11 January 2018 Amending Certain Laws to Increase Citizens' Participation in the Process of Election, Operation and Control of Some Public Bodies. Journal of Laws, 2018, item 130 [Ustawa z dnia 11 stycznia 2018 r. o zmianie niektórych ustaw w celu zwiększenia udziału obywateli w procesie wybierania, funkcjonowania i kontrolowania niektórych organów publicznych, Dz.U. 2018 poz. 130].

Act of 15 September 2000 on Local Referendum, consolidated text. Journal of Laws, 2016 item 400 as amended [Ustawa z 15 września 2000 r. o referendum lokalnym tekst jedn., Dz.U. 2016 poz. 400 ze zm.].

Act of 20 July 1983 on the System of National Councils and Local Self-Government. Journal of Laws, No. 41, item 185 as amended [Ustawa z 20.07.1983 r. o systemie rad narodowych i samorządu terytorialnego, Dz.U. Nr 41 poz. 185 z późn. zm.].

Act on Direct Elections of the Commune Head, Mayor and City President of 20 June 2002, Journal of Laws, No. 113, item 984 as amended [Ustawa z 20 czerwca 2002 r. o bezpośrednim wyborze wójta, burmistrza i prezydenta miasta, Dz.U. Nr 113, poz. 984 z późn. zm.].

Act on Government Administration in the Voivodship of 5 June 1998. Journal of Laws No. 91, item 577 [Ustawa $\mathrm{z}$ dnia 5 czerwca 1998 r. o administracji rządowej w województwie, Dz.U. Nr 91, poz. 577].

Act on Local Self-Government of 8 March 1990. Journal of Laws, No. 142, item 1591 as amended [Ustawa z dnia 8 marca 1990 r. „Ustawa o samorządzie gminnym”, Dz.U. 2001, Nr 142, poz. 1591 z późn. zm.].

Act on Poviat Self-Government of 5 June 1998, consolidated text. Journal of Laws 2018, item 995 [Ustawa o samorządzie powiatowym z dnia 5 czerwca 1998 r. tekst jedn., Dz.U. 2018 poz. 995].

Act on the Electoral Code of Poland of 5 January 2011, consolidated text. Journal of Laws 2018, item 754 [Ustawa z 5 stycznia 2011 r. Kodeks wyborczy tekst jedn., Dz.U. 2018 poz. 754].

Act on the Introduction of the Three-tier Division of the Country of 24 July 1998. Journal of Laws No. 98, item 603 as amended [Ustawa z 24 lipca 1998 r. o wprowadzeniu zasadniczego trójstopniowego podziału terytorialnego państwa, Dz.U. Nr 98 poz. 603 z późn. zm.].

Act on Voivodship Self-Government of 5 June 1998, consolidated text. Journal of Laws 2018 item 913 [Ustawa z dnia 5 czerwca 1998 r. o samorządzie województwa, Dz.U. 2018, poz. 913].

Buczkowski, P. (1997). Samorząd terytorialny u progu II kadencji. In P. Swianiewicz (Ed.), Wartości podstawowe samorząu terytorialnego i demokracji lokalnej. Warszawa: Municipium.

Dębicki, M. (2001). Urzędnik XXI wieku. In B. Kudrycka (Ed.), Rozwój kadr administracji publicznej. Białystok: Wyższa Szkoła Administracji Publicznej. 
Dębowska-Romanowska, T. (1994). Odpowiedź na ankietę "Prawo obywatela do samorządu". Samorzad Terytorialny, 11 .

Geremek, B. (2002). The transformation of Central Europe. In L. Diamond, \& M. F. Plattner (Eds.), Democracy after communism. Baltimore and London: Johns Hopkins University Press.

Izdebski, H. (1993). Wspótczesne modele administracji publicznej. Warszawa: Urząd Rady Ministrów.

Jakubowska, U. (2002). Przywództwo polityczne. In K. Skarżyńska (Ed.), Podstawy psychologii politycznej. Poznań: Zysk i S-ka.

Kasiński, M. (2009a). Etyczne i polityczno-prawne dylematy samorządu terytorialnego w Polsce. Annales. Ethics in Economic Life, 12(2) 141-153.

Kasiński, M. (2009b). Monizm i pluralizm władzy lokalnej. Łódź: Wydawnictwo Uniwersytetu Łódzkiego.

Kumaniecki, K. (1924). Centralizm i decentralizacja. In W. L. Jaworski (Ed.), Ankieta o Konstytucji 17 marca 1921. Kraków.

Kurczewski, J. (Ed.) (2007). Lokalne wzory kultury politycznej. Warszawa: TRIO.

NSZZ "Solidarność". (1989). Kierunki rozwoju samorząów terytorialnych w Polsce. Tezy programowe II 25.01.1989 r. [after: Wójcik, S. (1999). Samorząd terytorialny $w$ Polsce $w X X$ wieku. Lublin: Wydawnictwo Katolickiego Uniwersytetu Lubelskiego].

Piekara A. (2005). Samorzad terytorialny i inne formy aktywności społecznej dawniej i dzisiaj. Warszawa: Twigger SA.

Regulski, J. (2000). Samorzad III Rzeczypospolitej - koncepcja i realizacja. Warszawa: Wydawnictwo Naukowe PWN.

Stahl, M. (1988). System samorządu terytorialnego w ustawie lipcowej. In M. Seweryński (Ed.), Problemy samorzą społecznego. Łódź: Wydawnictwo Uniwersytetu Łódzkiego.

Staniszkis, J. (1989). Ontologia socjalizmu. Warszawa: In Plus.

Śliwiński, M. (2005). Analiza porównawcza systemów politycznych (Vol. 1). Drogi do wspótczesności. Warszawa: Wydawnictwo Uniwersytetu Warszawskiego.

Wnuk-Lipiński, E. (2000). Granice liberalnej demokracji. Znak, 256.

Wójcik, S. (1999). Samorząd terytorialny w Polsce w XX wieku. Lublin: Wydawnictwo Katolickiego Uniwersytetu Lubelskiego. 